\title{
Intermédialités
}

Histoire et théorie des arts, des lettres et des techniques

Intermediality

History and Theory of the Arts, Literature and Technologies

\section{Rendering Time (Basinski): an Interview with William Basinski}

\section{André Habib et Charlotte Brady-Savignac}

Numéro 33, printemps 2019

restituer (le temps)

rendering (time)

URI : https://id.erudit.org/iderudit/1065023ar

DOI : https://doi.org/10.7202/1065023ar

Aller au sommaire du numéro

Éditeur(s)

Revue intermédialités

ISSN

1920-3136 (numérique)

Découvrir la revue

Citer ce document

Habib, A. \& Brady-Savignac, C. (2019). Rendering Time (Basinski): an Interview with William Basinski. Intermédialités / Intermediality, (33).

https://doi.org/10.7202/1065023ar 


\section{Rendering Time (Basinski): an Interview with William Basinski}

The interview was conducted by André Habib, with the collaboration of Charlotte Brady-Savignac, on April I5, 2019.

$I_{1}$ AH: Looking at your albums, the word "time" appears a couple of times in your titles, and in the last two albums, On Time Out of Time and A Shadow in Time. Images of water also are recurrent: Vivian $\mathcal{E}$ Ondine, Cascade, Watermusic, The River. One knows the deep ties of time and water, with the notion of the "flow of time," etc. Are you able to explain the relationship your music entertains with time or temporality? How do you see time? And can we say one hears time in your music?

WB: It has always fascinated me, from the very beginning. The loops of memory, for starters: feedback loops, childhood memories. We remember bad things more than we remember good things, these things that turn into feedback loops, and then you can get caught in a trap. I had to figure out a way through my own bad feedback loops. Through my experimentations with tape loops and the physical nature of working with a piece of plastic, rust, and glue, I was able to reach a point where I was discovering innate melancholy inside muzak, for example. I started getting results, and when I would find the perfect loop, it could just go and you're, like, suspended there, out of time. These are the kinds of things that I like. Over the years I continued to develop what I wanted to hear. I like turning something on and just falling in, and losing track of time.

I You've talked about your discovery of the music of Steve Reich, and later Brian Eno, where the loop is an important motif. Is this something that you sought out very early on, that the loop would be some kind of precious thing that you would try and develop? How early on did that notion come to you? 
It's something I could afford to work with. I couldn't afford synthesizers, and for Io dollars I had two tape decks and a bunch of used tapes that I could work with for years. So, that worked well!

$I_{3}$ In order to find this perfect loop, you were recording sound off of different shortwave radios, recording the sound of your fridge, an air conditioner, etc. But how do you define this perfect loop? What makes it perfect?

For me, it's one that...you don't hear a beginning or an end, or if you do, it resolves itself into the beginning perfectly, and then it just flows. So, you're creating a kind of a vortex or a stargate-an escape hatch, if you will.

I4 I'd like to get back to this notion of time, because your work is-like the title of your last album may suggest, On Time Out of Time-in a sense, it is about a certain relationship to time. It's also out of time. As if a way of talking about time is going out of time, since the loop is a way of talking about time that contradicts the essence of time, which has to do with a certain linearity. So, there's an interesting relationship between the idea of change and the idea of this eternal presence provided by the loop. The loops are also about change, or evolution through a lapse of time. My question could be: how do you negotiate this question of temporality? Are you interested in this out-of-time experience? Are you trying with your music to make us understand how time works on a sensorial, experiential level?

I'm not trying to teach anything. With my work I use loops and drones, my rhythms come from nature: water, wind, cycles. When I get to a point in a piece where I think it's finished and I'm happy with it, then it's time to release a record and then to tour. But I find that a 40 -minute piece, when it works in a performance situation, can give everybody a little vacation and take everyone out of this crazy...I mean, scrolling, scrolling, scrolling, terror, terror, terror, aaaah, endorphins, endorphins_-give me a break! Yeah, that's what I'm trying to do.

$I_{5}$ To escape a certain regime of time and come back to actually experiencing time in a different, possibly more direct way?

Just a place of solace, or introspection. 
I6 Your work, when we listen to it, is also very much about the specificity of mediums, the mediums of sound, especially. You're very attentive to cracks, hisses, distortions, and echoes, and all these things that are the grain of the sound, the blurring, the white noise. Where do you stand now in relation to what is considered today-which wasn't the case when you started-obsolete technology: tape decks, magnetic tape? In the 1980 and 1990 s, these weren't considered obsolete. How has your relation to technology evolved when it comes to sound equipment?

I still love using my analog gear. It does something that computers can't do. I use computers now for other steps. I do have some virtual synths and some other synthesizers, and things that I've had since I started. My gear is my tools, it's what I work with. I was just at Moogfest, in North Carolina, ${ }^{\mathrm{I}}$ and besides music, it's a big technology festival, there's lot of geeks there, buying modules and building synthesizers. They're looking at all the gear and the new Moog synths, and they let me come in and play around with the new Moog One synthesizer. ${ }^{2}$ Very sophisticated. Luckily, there was someone there to help me guide my way through it. These days I have a terrific young engineer, Preston Wendel, who helps me in my studio, so I can, not really learn new tricks, but avail myself to some new things that I like to experiment with and that I'm not going to learn. So, it was fun playing around with this new monster.

I $_{7}$ Like you said, your analog gear does things that computers can't do. Most of these things refer to the frailty of the medium, this idea that the medium produces beautiful things when it breaks, when it disappears, when it hisses, when it's not doing exactly what it's supposed to do. The sound of shortwave radio contains this hiss. It is something that you're exploring also, this idea of frailty, which is also the frailty of our own lives, isn't it?

I Moogfest (https://www.moogfest.com/), which takes places in Durham, North Carolina, was created with the collaboration of the company Moog Music founded by the electronic music pioneer Robert Moog. For a history of the development of the company and the Moog instruments, see the interview with Robert Moog by Dominic Milano, "Bob Moog: From Theremin to Synthesizer," Keyboard, September/October 1975, uploaded on ${ }_{29}$ November 2017, https://www.keyboardmag.com/artists/bob-moog-from-theremin-tosynthesizer (accessed 30 May 2019).

${ }^{2}$ The Moog One synthesizers are described as "polyphonic analog" instruments; they were developed for the first time thirty-five years ago; see https://www.moogmusic.com/products/moog-one (accessed zo May 2019). 
Yeah, it's true. But these are things that you discover along the way. Just like when you have trouble in your life and these aren't things that you like at the time. There are tragedies- “Oh no, I fucked up!”- but these things pass and as you get older you prepare and learn how to deal with it. I enjoy when anomalous things happen early on in a creative process. It sparks something, it's like, "Oh, there is something, there is a scar, okay, I'm going to have to live with that." You learn how to do it.

98 And how do you negotiate this thing when related to-I guess between the performance and the record-do you still perform with analog loops?

I do, a bit, yeah. On the last tour I was taking two small Uher Report monitor tape decks with me, and they're small enough to carry on-they're heavy, but not too bad. This tour it's just one, so it's a little bit lighter. But yeah, there's a loop involved at the end of the new piece that isn't on the record. It's a little something special for everybody to show I'm making somewhat of an effort, instead of just doing the laptop.

I9 Does this change your performance? Your work was initially performance-based, and it was later in your career that you started recording, right?

One-time performance that you better be recording.

I $_{10}$ But how has your performance evolved? You're not performing the same things, you're not doing exactly the same things. How do you see the evolution of your own practice as a performer?

It depends on the show. The performance is more like a presentation. It's electronic music, I'm not playing modular synths, I'm not plugging it in and doing a whole new piece every time - that's impossible. But the performance is about going to a different space every day or every couple of days, having an hour with the sound guys, finding the resonance frequencies in the room. This new piece, in particular, has a lot of bandwidth, there's a lot of particular frequencies that can cause problems, so we have to check and see how it works. Sometimes it's like, "Wow! I can't believe it. Those low mids [low midrange's] aren't blowing up the universe!” And then other times we have to tweak some things and find a way where we're not going to be rattling 
stuff, and the volume level... And so there's a lot of work that gets done in this onehour sound check with the technician, and we work together to set up the sound, maybe a few minutes to talk to a lighting designer that might be there. We have a lighting plot for the show that we ask for, and sometimes we get it. It's a multimedia experience. I'm pretty much standing there, monitoring, listening very carefully, in a black sequin jacket, just trying to put out a little sparkle. I do what I can. And it works because it's really about the music. I mean, we could do it in a dark room, but you have to take into consideration for a performance that people want to take pictures, people want a visual experience. So, we're doing this trippy, fog-and-lights, fly-intothe-universe show.

\section{$g_{n} \quad$ Were the visual components, the projection, part of your performances early on?}

James Elaine ${ }^{3}$ and I have been working together since we met, forty years ago. He's a brilliant artist and filmmaker, and started working with Super 8. In the 1990s, Panasonic had these very cool little video cameras that weren't very big and had some new features on them that could make it look like film. Jamie likes the AG 3 model, and he was doing really interesting stuff with that, just with changing focus and focal length, setting it up in natural settings at his farm in Texas, for example, on the lake. For different pieces he would come up with something and I would be like, "Oh, great, this is perfect! We'll take that, we'll use that this time as a projection.” For Nocturnes (2013), we had been on the island of Pantelleria [Sicily] one summer, and we had just gotten there, and it's a long way from L.A. It was a full moon rising up over this island in the Mediterranean, through clouds, puffy clouds. And he just flopped into a butterfly chair and he sat there with the camera for an hour, until the tape ran out. He has a really steady hand, it's incredible. This was just beautiful film. That one I used for the Nocturnes tour, which worked really nicely.

3 James Elaine is a painter, videomaker, and curator who was affiliated with the Drawing Center in New York and the Hammer Museum at the University of Los Angeles before relocating to China where he now lives and works. For more information on Elaine's career, see the interview with Paul Glader, "An American in China: From L.A. Curator to Gallery Founder in Beijing," Forbes, 26 July, 2015,

https://www.forbes.com/sites/berlinschoolofcreativeleadership/2015/07/26/anamerican-in-china-from-l-a-curator-to-gallery-founder-in-beijing/\#6b7icecaroco (accessed 30 May 2019). 
$g_{12}$ The visual component is also very important for another one of your works, Disintegration Loops, ${ }^{4}$ which we need to talk about. It is a masterpiece in your career. It's a major piece, but it's a piece also where, like in some of your music, it has to do with letting something happen, letting the sound do its own thing, in a way. It's something that I'm interested in, in your work. There's obviously a choice, there's obviously a mastery involved in this. But it's also very much about letting go, letting the loop go, letting the music disintegrate, letting things happen, letting time settle in. I'm wondering if you're able to reflect on that aspect of your work: this idea of letting go, how crucial is it? Peter Hutton, the filmmaker,'s says that the hardest thing is not doing anything. Is it something that you're interested in?

Yeah, it's something that one learns as one gets older. As a young composer, I was first starting out in San Francisco, making these loops there, and then we moved to New York in 1980, in a whole new environment, continuing with that, pulling sounds out of the airwaves. The most powerful radio station in the city was at the top of the Empire State Building and just blasting muzak everywhere. We had a big loft with wires running all around the speakers, and the strings, the thousand and one strings would come in, whether you wanted it or not, up in there. I wanted a Mellotron. ${ }^{6}$ I thought, "Okay, I'll try to make one with little snippets here and there.” I knew they were made with tape loops, and this was a taking off point. Also, getting something from nothing and seeing what could be done with that; taking things out of the airwaves. At that stage, sometimes I'd record a little bit, slow down, "Oh yeah, that's cool," sometimes it was like, "Oh, wow, that's incredible!” What I wanted to do was mix things together. I wanted to be involved. Like Shortwave Music (1982) and The River (2003), I'm mixing things live with this shortwave radio just doing its thing along in there. And some of these other loops would go to the side, because I knew, well, they're perfect. But at the time I was too immature and not far enough along to know if I could really call that my work, it seemed too easy or something. But I knew it was good! I was like, "Okay, you're good.” Well, twenty years later,

${ }^{4}$ The Disintegration Loops I-IV were released in 2002 and 2003 , resulting from former magnetic tapes recorded in the 1980 s, which disintegrated as Basinski started to play them, two decades later.

5 Peter Hutton and William Basinski, Time and Tide, 2000.

${ }^{6}$ A polyphonic keyboard developed in England in the 1960s. For a short history of the instrument, see Mark Radcliffe, "Sampledelica! The History of the Mellotron," podcast broadcast by BBC Radio 4, 8 August 20I4, https://www.bbc.co.uk/sounds/play/boo76ylh (accessed 30 May 2019). 
these loops that were perfect, but a little scary, turned up in the cue to be archived on that particular day in the end of July, in 20oI, and I was like, "Oh, wow! Boy, do I need this now." The first one, the grave and beautiful Disintegration Loop I.I, got put on, and I started making a countermelody, on the Voyager Synthesizer, and nice, randomly arpeggiating a kind of a French horn sound, and it was sounding nice, so I just started recording, I'm like, "I got a new piece, this is great." Well, of course, it started to change about Io or Is minutes in, and I was like, "Uh-oh." I mean, I knew this could happen - this is what happens to tape. The tape was old when I bought it in 1978 . The glue disintegrates and then the iron oxide falls off, and the plastic lasts forever. So, that happened and I was just making sure I was recording. Then I put the second one on and started another kind of countermelody. I didn't know they were all going to do this. I was like, "This is cool." Then the second one started doing the same thing, and after that I realized, "Ah, you don't need countermelodies, just get out of the way, pay attention, and make sure you're recording this, because this is incredible!” You learn to step back and just make sure your levels are good-at one point or another.

$I_{13}$ So, out of the six loops, a couple of them are redoubled, so to speak (there's a 2.I, 2.2, a I.I, a I.2, a I.3)? Were there a couple of loops that you didn't use?

No. They all went in order of the way it happened. I had a couple of other little takes of Disintegration Loop $I$ at the end, which I ended up putting at the end, I.2 and I.3. They're interesting too because they're a little bit different. One of them, I think it's I.3, the tape loop actually starts slipping off the head and stops for a second, then it comes back in, and it does it again. It's like, “Oh, god!”

\section{$9_{14}$ Did you try performing Disintegration Loops at the time?}

I couldn't, that was a one-time performance, those loops are almost entirely clear now. But we had them transcribed; Maxim Moston, 7 my colleague who I met when we were both in Antony and the Johnsons, did transcriptions for me. They've been performed six or seven times around the world now. We just had a world premiere of a new transcription of Disintegration Loops 3 by Robert Ames, maestro of the

\footnotetext{
${ }^{7}$ Maxim Moston is an American performer, arranger, producer ${ }_{2}$ and composer; see the
} artist's website, http://maximmoston.com/ (accessed 30 May 2019). 
wonderful Manchester Camerata in Manchester, ${ }^{8}$ which was very beautiful. These things have to go into the orchestral repertoire, and that's where they're going to be. As long as we have electricity, the digital files will be out there. But for a performance of that material-it's incredible to watch real, professional, trained musicians go through these very difficult scores and do them with one rehearsal; one day of rehearsal usually is all you get, because it's so expensive.

\section{Who suggested first to do an orchestral transposition of The Disintegration Loops?}

Well, it has been a dream of mine. In the spring or late winter of 20II, I heard from Ronen Givony, ${ }^{9}$ who is the one that started the Wordless Orchestra in New York, and just a terrific impresario-Le Poisson Rouge, ${ }^{\mathrm{IO}} \mathrm{I}$ believe he is still booking-and he was like, "Hey, do you want to do anything?" And I was like, "Well, I've been dying to see about getting Disintegration Loops into the repertoire.” And he's like, "We can do that." And I was like, "Oh, wow, great! Okay!" Then he calls me back, "You know, let's try to do something for around-it will be the Ioth anniversary of $9 / \mathrm{II},{ }^{\mathrm{II}}$ we could get a church or something.” I was like, “Okay!” I was working on the

\footnotetext{
${ }^{8}$ The concert Basinski the Disintegration Loops occurred at Albert Hall, Manchester, UK on II April 2019.

9 Ronen Givony is founder of Music Worldless, a festival that pairs up rock and electronic musicians with classical music performers. See the interview by Norman Middleton for the Library of Congress, "A Conversation with Ronen Givony and Tyondai Braxton," Io March 20II, https://www.loc.gov/item/webcast-544I (accessed 30 May 2019).

${ }^{10}$ As described in its website, "(Le) Poisson Rouge is a multimedia art cabaret founded by musicians on the site of the historic Village Gate. Dedicated to the fusion of popular and art cultures in music, film, theater, dance, and fine art, the venue's mission is to revive the symbiotic relationship between art and revelry; to establish a creative asylum for both artists and audiences" "“About," Le Poisson Rouge, https://lpr.com/about/ [accessed 30 May 2019]).

"I A memorial concert was organized on Io September 201 in the Temple of Dendur at the Metropolitan Museum of Art, with the world premiere of Maxim Moston's orchestration of The Disintegration Loops I.I performed by the Worldless Music Orchestra, with Ryan McAdams as conductor. The program also included Ingram Marshall's Fog Tropes II, Osvaldo Golijov's Tenebrae, and Alfred Schnittke's Collected Songs Where Every Verse is Filled with Grief, as arranged and generously provided for this concert by the Kronos Quartet. The concert was recorded and can be heard as an archive stream on NPR at https://www.npr.org/sections/deceptivecadence/20II/09/07/I40265002/rememberingseptember-II-a-live-concert-webcast-from-the-temple-of-dendur (accessed 3 May 20I9).
} 
workshops for Robert Wilson's Life and Death of Marina Abramovic opera, ${ }^{12}$ for which Anohnir' invited me to help to do the music for them. So we were in Anohni's apartment in New York, later that spring, pulling together what I was bringing, Anohni's songs, and the boys that were going to be in the pit band, Matmos ${ }^{14}$, Gael Rakotondrabe, Oren Bloedow and Doug Wieselman of The Johnsons. I said to Anohni, "Wordless Music wants to do...we're talking about transcription for Disintegration Loops, who should I ask?" And he's like, "Oh! Ask Max [Maxime Moston].” I said, “Okay.” Max came over for visit and I said, "Max, blah-blah-blah. We want to do this, do you want to do it?” He's like, “I'd love to!” He already knew the work, like everybody in New York after it came out. He was very familiar with it. And he's brilliant! His ears...I mean, he finished school and learned how to orchestrate (unlike me), and is a genius violinist, conductor, guitarist, arranger, and everything - so it was perfect! He worked on it over the summer. A dear friend and patron of mine, Lauren Bon of The Metabolic Studio jumped in and wanted to pay for the whole thing. Then, all of a sudden, the Metropolitan Museum had a new music curator who's friends with Ronen who heard about it and was like, "We want it for the...we don't have anything!" So, all of a sudden, that's what was going to happen - and it did. In the Temple of Dendur: 8 oo people, and 300 people not able to get in. It was incredible! At the end there was, like, three moments of stone silence, like the whole audience had been turned into Isis and Osiris by magic. Then a plane went by, or a motorcycle, I can't remember what, but this drone came up playing the same F note and went away, and then it was just like, “Oh, my god!” Everybody went nuts! That was quite a magical experience, and I've heard from many people that it was something they'll never forget for the rest of their lives. Especially people who were there in New York and know what happened.

It's one of the most wonderful paradoxes, in a way, that this work is also returning the music back to its origins, right? At some point this music was orchestral; it went from radio to tape, from tape to digital, and now back to orchestra. Which, in a way, is a wonderful loop.

${ }^{12}$ The Life and Death of Marina Abramović by Robert Wilson and Marina Abramović, 20II. Antony (music); William Basinski (composer and music curator); Jacques Reynaud (costumes); Wolfgang Wiens (dramaturgy); Nick Sagar (sound design).

${ }^{13}$ Anonhi, previously known as the artist Antony from Antony and the Johnsons.

${ }^{14}$ Matmos is an experimental music duo formed by M. C. (Martin) Schmidt and Drew Daniel; they have collaborated with Björk. See their official website http://vague-terrain.com/ (accessed 30 May 2019). 
It's true, I never thought of it that way. But you got it!

$I_{17}$ The Disintegration Loops has meant so much to so many people, and it has taken up many meanings, especially in relationship to 9/Ir: it has embodied, allegorized in a way, the event, the trauma. It has some sort of consoling, soothing dimension to it, which is very strong. How do you see, in your own work, in your own perception of it, its evolution through time? You've often said it was a way to say goodbye to your youth, when you were doing them. In retrospect, how do you see the work today? How do you see its evolution?

Well, it launched my career. I was at the end of my rope. I had a long conversation, very intense one, on the phone with Jamie, the night before that. I was not going to make it the next morning, you know, I was over everything. And then everything changed-dramatically. And it was: "Back to work. This is important." I made that film the last hour of daylight, on September IIth, that night after we were in shock and, like, "Fuck!" The next morning, putting it with the music, and like, "Oh my god. Well, this is an elegy now, the work is changed, everything is changed and the whole world is changed. Where are we going?" And from the looks of where we are now, it's still disintegrating. We're at number 4 right now, which cascades into chaos very quickly. Hopefully, we can get to numbers 5 and 6 pretty soon.

$9_{18}$ But the work, is it a work that you can still listen to? Does it still bring you joy?

Sure! It was a magical experience. Doing these things at twenty-two and then finding them at already whatever, and having that happen, and then actually having the critics...nobody knew who I was then. I couldn't put out a box set, because I couldn't afford it, so I decided to do them one at a time, put some more money on my credit card, and did it. And then the critics went nuts.

$I_{19}$ How did that happen? The first iteration of The Disintegration Loops was basically self-produced or self-distributed. And how did it get into the hands of the right people?

Well, I had a lot of help from friends. 
$I_{20} \quad$ This was before Facebook...

Yeah, a couple of years before, Steve Roden, ${ }^{15}$ who is an incredible artist and sound artist who had had some releases, and whom I had met through Jamie-because for years, Jamie's day job was emerging art curation in New York and then here, at the Hammer Museum in Los Angeles, for ten years, so he knew all these amazing people-and we would become friends. I had done Watermusic in 2000 and I didn't know what to do with it. I asked Steve and he gave me a list of about twenty-five names; all ended up being very important people, many of whom are my friends now, and to whom I sent the CDR and a little letter. It was Richard Chartier, Taylor Deupree, Giuseppe Ielasi in Italy, Massimo Ricci, a critic in Italy, ${ }^{16}$ a bunch of other people. There might have even been a distributor on there. Everyone loved it. So, I had a distributor who would take some, and so I was getting out there.

\section{$g_{21}$ Did the letter explain what they were listening to? How explicit was it?}

It might have, it was a short letter, might have mentioned-I can't remember. I'll have to look up the letter. But anyway, these were all people who were into minimalist, "lower case music," they called it. And so that got me a start. A few years before that Carsten Nicolai [aka Alva Noto] had released a small edition of Shortwave Music on Raster-Noton on clear vinyl that just sort of disappeared, ${ }^{17}$ but some people got that, and they knew. I wasn't even on the Internet until, like, Spring of 2oor, so I never knew anything about what was going on, or anything like that. Then, by the time Disintegration Loops happened, I was calling everybody: "Oh my god, get over here, you won't believe what's happened!” Anohni came over, my friend Howard

is Steve Roden is an American visual and sound artist; see his website at http://www.inbetweennoise.com/bio/ (accessed 30 May 2019).

${ }^{16}$ Richard Chartier is a Los Angeles-based visual artist and composer specializing in minimal art, https://www.3particles.com/bio (accessed 30 May 2019); Taylor Deupree is a musician and interdisciplinary artist active, namely, in USA and Japan, https://www.taylordeupree.com/ (accessed 23 July 2019); Giuseppe Ielasi is a musician based in Italy who developped an approach to sound that he describes as close to sculpture, see the interview with Tobia Fischer, on Tokafi http://www.tokafi.com/Isquestions/I5-questionsgiuseppe-ielasi/ (accessed 23 July 2019); Although Massimo Ricci describes himself as a musician, refusing the title "critic," his writings are published on his website https://touchingextremes.wordpress.com/ (accessed 3o May 2019).

${ }_{17}$ Opto Files, 200 . 
Schwartzberg ${ }^{18}$ - an amazing artist I talked about many times, super smart. He's from Coney Island, so he has a crazy Coney Island accent: "Billie! You've done it! This is it!” He was right. He knew, he studied art. He knew deconstructionism and all that kind of stuff, which I didn't know anything about at the time. Anohni's career was really starting to take off, and she knew all these important people in England, in London-David Tibet ${ }^{19}$ - and sent music over there to these people, and they were all going crazy about it and started communicating with me. When it was ready to be released, I had a pretty big American distributor, and then I started having distributors in Europe. I was doing everything piecemeal and when David Keenan's feature on it came out in The Wire magazine, ${ }^{20}$ right after it came out, in the summer of $2002-I$ cried. It was so wonderful. And it just took off from there. A couple years later, when Pitchfork and Mark Richardson, I think it was, wrote this incredible review, ${ }^{21} \mathrm{I}$ was at Jamies' little bungalow in Venice Beach and I had been selling records, so I had boxes of CDs there. I remember it was Good Friday 2004, or something like that, and all of a sudden my inbox was full of "Disintegration Loops," "Disintegration Loops," "Pitchfork" - I didn't even know what Pitchfork was. So that really set it off. In a couple of years, I got out of 30,000 dollars worth of debt and was able to keep going and keep releasing records. Now I'm just trying to serve in the way that I can, to fight the war with beauty.

It's working! For a great many of us, it's working. I'd love to hear you talk about your last album, which you described as "two black holes fucking." We have a picture now of one black hole, at least, to accompany the piece. Could you tell us a little bit about how that project emerged and what are we actually listening to?

i8 Howard Schwartzberg is an American visual artist; see his website at http://www.howardschwartzberg.com/home.html (accessed 30 May 2019).

19 Artist David Tibet is founder of Current 93, see his website at https://www.davidtibet.com/ (accessed 3 June 20I9)

${ }^{20}$ William Basinski, “The Disintegration Loops," feature review by David Keenan, The Wire, $\mathrm{n}^{\circ}$ 222, August 2002, p. 6r.

${ }^{21}$ The review was written in 20I2, on the occasion of the CD box set release. See Mark Richardson, "William Basinski, The Disintegration Loops," Pitchfork, I9 November 2012, https://pitchfork.com/reviews/albums/I7064-the-disintegration-loops/) (accessed 30 May 2019). 
This piece came about through two of my dearest friends, the brilliant art scientists Dmitry Gelfand and Evelina Domnitch. ${ }^{22}$ They're presently living and working in La Hague and have a laboratory there, and do all this really incredible work. Their website is called Portablepalace.com for people who would like to-and I highly encourage it-look at these two fabulous creatures and their amazing work. Anyway. They were here, at CalTech [California Institute of Technology], working with scientists like they do, working on a project they were interested in that deals with fluid dynamics. ${ }^{23}$ Basically, through this wave-forming pool they created, they're trying to show how two black holes create wormholes. For this one installation they had this big tank of water and they developed this nice little wave-making thing that would send two counter-clockwise-rotating vortices down through the pool. It's lit by a laser beam and you can see how the tails will join. That's one of the pieces. I saw them doing a lecture - their lectures are amazing — and after the lecture there was a cocktail party and one of the scientists ${ }^{24}$ from LIGO, the Laser Interferometer Gravitational Wave Observatory, ${ }^{25}$ which discovered gravitational waves a few years ago, was working with them down there-he is at CalTech, Jamie Rollings is his name. It turned out he was a fan, wanted to meet me, and so Evelina introduced us. We were talking and he said, "Hey, would you be interested in hearing these sounds and maybe doing something with them?" I was like, "Yeah! I would! That'd be cool!" Eventually, they sent me some stuff, in different files. I believe some of them were slowed down and time-compressed, and all kinds of other things, so you could hear, maybe analyze, what this click contained inside of it. Around that time the curator Isabelle de Sena ${ }^{26}$ who had put them together down in CalTech, was curating a big art science exhibition at Martin Gropius Bau in Berlin, a couple of summers ago. Dmitry and Evelina asked me to do a soundtrack for one of their installations. I used

\footnotetext{
${ }^{22}$ Gelfand and Domnitch are working together on immersive installations exploring the perception of wave phenomena.

${ }^{23} E R=E P R, 2017$, installation, in collaboration with William Basinski, Jean-Marc Chomaz and LIGO, see http://www.portablepalace.com/erepr.html (accessed 30 May 2019).

${ }^{24}$ Rana Adhikari, professor in experimental physics at the California Institute of Technology.

${ }_{25}$ See their website, https://www.ligo.caltech.edu/ (accessed 30 May 2019).

${ }^{26}$ Isabelle de Sena is independant curator and editor, specializing in aesthetics and philosophy of science. On the occasion of the interdisciplinary programme "Limits of Knowing" by Berliner Festspiele/Immersion, she curated the exhibition Arrival of Time, in collaboration with Rana X. Adhikari, Berlin, Martin Gropius Bau, July I to 31, 20I7; see https://www.berlinerfestspiele.de/en/berliner-festspiele/programm/bfsgesamtprogramm/programmdetail_213077.html (accessed 30 May 2019).
} 
this science they sent me, I sent it over to them, and they were like, "Oh, well, okay...well, you know, it's good but...” I'm like, "What? I was trying to stick to the science.” They're like, "No! We want you!” “Oh, okay, I get it. Alright, let me play around with it a little bit." I got out my-I want to call it my dolls and dishes-and you got to understand, doing a sound piece in a museum for an installation is something that you really have to think about, because the people in the museum have to hear this all day long, every day. And if they don't like it, it can maybe not get turned on. So, these are considerations. Anyway, I fixed it and they really liked it, and so, okay, that was good. The museum people wanted me to come and they commissioned me to do a performance at the opening, and that's when I came up with the long piece On Time out of Time. ${ }^{27}$ Really dug into it until it started to breathe, did all sorts of things, and found a way to have it...just imagining these waves travelling throughout galaxies and coming towards Earth, and life... You know, I.3 billion years - the Earth changed quite a lot in that period of time. I made a very romantic ending for the love story with this kind of perpetually almost resolving, but not quite resolving, denouement at the end, and then just kind of leaving it with the clicks again, from the LIGO installation.

$I_{23}$ It works beautifully. How do you see your music in terms of performance versus record? I mean, is it for you two different entities, or together? Is it a work that is, in your view, best served in a performance context? What is your relationship to the record, basically?

I love the way the record turned out. I think it sounds great, it was mastered beautifully by Lawrence English. I love the way the pictures came out. Everything about it sounds great. But performance is different: you're with people, the audience is excited to be there. My audiences come because they know what they're in for, mostly, it's not a lot of random people anymore. They're ready to go there and hear this on a massive state-of-the-art Meyer sound system, in a beautiful auditorium or church, or something that has amazing sound built by masons. These are all musical instruments in themselves, and to be able to resonate these places with the right volume level...I mean, I'm not a noise artist, I want to find how the music will float around in the room and space so you can just sit there and enjoy it. In a way you can't enjoy it at home. Most people don't have the ability to have a massive sound system they can blast the thing on in their house without disturbing neighbours. A lot of

\footnotetext{
${ }_{27}$ Released as an album in March 2019, under the label Temporary Residence.
} 
people just have headphones on laptops, and things like that. So, the performance is a special thing. You get to go to church almost.

I $_{24}$ Your music is also listened to while people do other things. It's a great music to work on-I can't tell you the number of articles I've written listening to your music. I owe you a lot in that respect in terms of creativity.

My fans are creative people all over the world, and I love it! If I can facilitate an environment where concentration can take place, that's great, that's exactly what I'm trying to do.

I $_{25}$ But having listened to you in concerts, you are clearly listening and living a very different experience. It's very fulfilling and mind-changing and life-changing, in a way. I was wondering if your relationship to your music remained essentially an intuitive, sensual thing, or have you gone reading oriental philosophy, different theories about time, and started thinking about your music on a more theoretical level? It has been obviously analyzed and discussed; I've read a number of articles that take your work and kind of give it philosophical or theoretical resonances. Is it something that you're interested in?

It's not my job, I have enough to do. Not that I don't love to read, I do. I wish I could just stay home and read, I have a huge library in my new house, the house that I was able to buy by the grace of God and people buying my work and paying for my shows. I never thought I could ever buy a house. Last year-hasn't even been a year-and I have been on the road the whole time, so this summer I want to do some work on the house and take a break and enjoy it. I just bought a solar system!) (solar power) That is being installed this summer.

$I_{26}$ Your relation to the music has remained essentially, and with good reason, a more intuitive and sensual experiential-based thing?

I don't start out with a concept and try to realize it. I start out with a kind of a sick feeling and depression, it's like, "Oh, you're pregnant! Go have a baby. Get to work!” An idea might come from a loop or something like that and then it's like, "Okay, I'm going to go with this and we'll see where this goes.” 
$I_{27}$ It's like chance encounters in a way: you meet someone, in the same way you could meet a sound, or just chance operation occurs, and kind of embrace them, right?

Yeah, love at first sight? But collaborating too is nice. I don't do a lot of it, but I have. I love the new record with Lawrence English ${ }^{28}$ that came about very quickly last year. We just did a bunch of touring of that in Europe, some amazing places, fabulous sound systems - that was real fun. It's fun being with someone else for a change, too.

I $_{28}$ How do you work with Richard Chartier, for instance, when you guys worked together on the two records?

We sent files back and forth and now that we both live in the same city, since we have different sound systems and things, I can go over to his house and hear what he is hearing. We can be there together, so that's nice.

$I_{29}$ I suppose you also work on your side, you send something, he adds a certain layer, sends it back...

Yeah, it's like playing tennis, you know.

$I_{30} \quad$ Ubiquity of modern technology, which is wonderful in that respect. Is there something that you're working on now, is there some record or some project you have in mind?

Yeah, I want to fix my house. I just did two records and toured for five years. I need a break. I'll get to something sooner or later, but people might not really understand: I'm still kind of doing everything by myself, in a way, by the seat of my pants. I do have a great international distributor now, Secretly Distribution, and I work with Jeremy at Temporary Residence, ${ }^{29}$ and they're a great help with the manufacturing and everything. I don't have to do any more distribution, publicity, all that. I have my fabulous manager and agent, Danilo Pellegrinelli of Shaktimusic.ch, in Europe.

\footnotetext{
${ }_{28}$ William Basinski and Laurence English, Selva Oscura, 2018, Temporary Residence.

${ }_{29}$ The experimental music label Temporary Residence was founded in 1996 and is now based in Brooklyn; see https://www.temporaryresidence.com/(accessed 30 May 2019).
} 
But I still have to do a lot of office work, emails, paperwork, and interviews, things like that. I'm trying to do everything I can to give everybody what they need, as I can.

I $_{31} \quad$ PS. As of early August I am actually working on a new record from deep within the loop archive. I'm quite excited about it and hope to release it next year. It's a bit dark as are these times. 


\title{
Rendering Time (Basinski): an Interview with William Basinski
}

\author{
André Habid, Université de Montréal \\ Charlotte Brady-Savignac, Université de Montréal
}

\section{BIBLIOOGRAPHICAL NOTES}

ANDRÉ HABIB is Associate Professor of Film Studies at the Université de Montréal. He is the author of L'attrait de la ruine (Éditions Yellow Now, 20II) and La main gauche de Jean-Pierre Léaud (Boréal, 20I5). He has coedited several publications and has been editor-in-chief of the web journal Hors Champ since 2016. He has written on the work of Jean-Luc Godard, Roberto Rossellini, Gustav Deutsch, Bill Morrison, Karl Lemieux, Ken Jacobs, Hollis Frampton, Angela Ricci-Lucchi, and Yervant Gianikian. His research focuses on found-footage filmmaking and the archive, experimental cinema, cinephilia, and, more recently, technostalgia.

Charlote Brady-Savignac is a PhD candidate (SSHRC 20i8-2022) in Film Studies at the Université de Montréal, under the supervision of professor Serge Cardinal. Her thesis focuses on repetition and musicality of the audiovisual complex in contemporary installation practices. She holds a Master's degree in Cinema, with a focus on the interferences between structural film and repetitive music. She is also involved as a research assistant in the international and interdisciplinary research group Archiver le présent and is a member of the research-creation laboratory La création sonore. 